\title{
Improvement in Hydrogention and Dehydrogenation Characteristics of Magnesium by Addition of Titanium (III) Chloride via Transformation- Accompanying Milling
}

\author{
Myoung Youp SONG ${ }^{1 *}$, Seong Ho LEE $^{2}$, Young Jun KWAK ${ }^{2}$, Hye Ryoung PARK ${ }^{3}$ \\ ${ }^{1}$ Division of Advanced Materials Engineering, Hydrogen \& Fuel Cell Research Center, Engineering Research Institute, \\ Chonbuk National University, 567 Baekje-daero Deokjin-gu Jeonju, 54896, Republic of Korea \\ ${ }^{2}$ Department of Materials Engineering, Graduate School, Chonbuk National University, 567 Baekje-daero Deokjin-gu \\ Jeonju, 54896, Republic of Korea \\ ${ }^{3}$ School of Applied Chemical Engineering, Chonnam National University, 77 Yongbong-ro Buk-gu Gwangju, 61186, \\ Republic of Korea
}

crossref http://dx.doi.org/10.5755/j01.ms.23.3.16375

\section{Received 07 October 2016; accepted 06 December 2016}

\begin{abstract}
A specimen consisting of $90 \mathrm{wt} \% \mathrm{Mg}$ and $10 \mathrm{wt} . \% \mathrm{TiCl}_{3}$ (called $90 \mathrm{Mg}+10 \mathrm{TiCl}_{3}$ ) was made by transformationaccompanying milling, and its hydrogenation and dehydrogenation features were checked. The activation of $90 \mathrm{Mg}+10 \mathrm{TiCl}_{3}$ was not demanded. $90 \mathrm{Mg}+10 \mathrm{TiCl}_{3}$ revealed an useful hydrogenation-dehydrogenation capacity (the quantity of hydrogen absorbed in $60 \mathrm{~min}$ ) of about $5.6 \mathrm{wt} . \%$. At $\mathrm{C}_{\mathrm{n}}=1$, the specimen absorbed $4.06 \mathrm{wt} \%$ of hydrogen in $5 \mathrm{~min}, 5.09 \mathrm{wt} . \%$ of hydrogen in $10 \mathrm{~min}$, and $5.59 \mathrm{wt} \%$ of hydrogen in $60 \mathrm{~min}$ at $593 \mathrm{~K}$ in $1.2 \mathrm{MPa}_{2}$. At $\mathrm{C}_{\mathrm{n}}=1$, the specimen desorbed $0.47 \mathrm{wt} . \%$ of hydrogen in $2.5 \mathrm{~min}, 3.81 \mathrm{wt} . \%$ of hydrogen in $30 \mathrm{~min}$, and $5.20 \mathrm{wt} \%$ of hydrogen in $60 \mathrm{~min}$ at $593 \mathrm{~K}$ in $0.1 \mathrm{MPa} \mathrm{H}_{2}$. The XRD pattern of $90 \mathrm{Mg}+10 \mathrm{TiCl}_{3}$ dehydrogenated at the $4^{\text {th }}$ hydrogenationdehydrogenation cycle included $\mathrm{Mg}, \beta-\mathrm{MgH}_{2}, \mathrm{MgO}$, and a small amount of $\mathrm{TiH}_{1.924}$ phases. The $\mathrm{P}$ (equilibrium hydrogen pressure)-C (composition)- $\mathrm{T}$ (temperature) curve at $593 \mathrm{~K}$ revealed an equilibrium plateau pressure at about $0.25 \mathrm{MPa} .90 \mathrm{Mg}+10 \mathrm{TiCl}_{3}$ had a higher early hydrogenation rate and a larger amount of hydrogen absorbed in $60 \mathrm{~min}$ than $\mathrm{Mg}, 90 \mathrm{Mg}+10 \mathrm{Fe}_{2} \mathrm{O}_{3}, 90 \mathrm{Mg}+10 \mathrm{MnO}$, and $90 \mathrm{Mg}+10 \mathrm{TaF}_{5}$, the hydrogenation and dehydrogenation features of which were before informed of.

Keywords: hydrogen storage, magnesium-based alloys, transformation-accompanying milling, hydrogen sorption rates.
\end{abstract}

\section{INTRODUCTION}

The storage of hydrogen using metal hydrides as hydrogenation and dehydrogenation media has several strengths over storage by compression, storage by liquefaction, and storage by adsorption with carbon nanotube: metal hydrides own a higher hydrogenation and dehydrogenation capacity on the basis of volume and hydrogen storage by metal hydrides is safer than storage by compression and storage by liquefaction. To release hydrogen out of metal hydrides, squandered heat can be employed. Besides, selective hydrogen storage and release of metal hydrides enables us to produce hydrogen with high purity [1].

Magnesium owns a high hydrogenation and dehydrogenation capacity (7.6 wt.\%), is of relatively low price, and has a great deal of deposit in the earth's crust. However, it has low hydrogenation and dehydrogenation rates. Much research to heighten the hydrogenation and dehydrogenation rates of magnesium has been conducted by preparing magnesium and transition metal alloys [2] such as Pd [3], Ni [4], Sm [5], Ni and B [6], Pr and Ni [7], and $\mathrm{Sc}, \mathrm{Ti}, \mathrm{V}, \mathrm{Cr}, \mathrm{Y}, \mathrm{Zr}, \mathrm{Nb}$, and $\mathrm{Mo}$ [8], and by making magnesium and transition metal compounds like $\mathrm{Mg}_{17} \mathrm{Ba}_{2}$ [9].

Ma et al. [10] reported that $\mathrm{TiF}_{3}$ improved the

\footnotetext{
*Corresponding author. Tel.: +82-63-270-2379; fax: +82-63-270-2386. E-mail address: songmy@jbnu.ac.kr (M.Y.Song)
}

absorption/desorption kinetics of magnesium hydride $\left(\mathrm{MgH}_{2}\right)$ superiorly over $\mathrm{TiCl}_{3}$. Both $\mathrm{TiF}_{3}$ and $\mathrm{TiCl}_{3}$ additives generated highly dispersed active $\mathrm{TiH}_{2}$ phase and inactive magnesium halides. The reaction of $\mathrm{TiCl}_{3}$ with $\mathrm{MgH}_{2}$ produced $\mathrm{TiH}_{2}$ and $\mathrm{MgCl}_{2}$.

Magnesium hydride milled with different halides was prepared by Malka et al. [11] to check the optimum percentage of added halide and preparing conditions. They investigated the influences of these added halides on the dehydrogenation temperature of $\mathrm{MgH}_{2}$ and the decrease in activation energy for dehydrogenation. Catalytic efficiencies of the chlorides and fluorides of the different metallic elements in the samples were compared. Considering electronic states of the metals in selected halides, the effects of the selected halides on $\mathrm{MgH}_{2}$ decomposition temperature were also discussed. They informed of that $\mathrm{TiCl}_{3}$ was one of the halides with the best catalytic effects for the dehydrogenation of magnesium hydride, among the studied halides.

The influence of 7 wt.\% dopants, such as $\mathrm{ZrF}_{4}, \mathrm{TaF}_{5}$, $\mathrm{NbF}_{5}$ and $\mathrm{TiCl}_{3}$, on the kinetics of absorption and desorption of magnesium hydride was studied by Malka et al. [12]. They reported that the valence state of the metal halides changed during processing and $\mathrm{NbF}_{5}, \mathrm{TaF}_{5}$ and particularly $\mathrm{TiCl}_{3}$, took part in the disproportionation reactions that created a significant amount of structural defects. 
In the present study, $\mathrm{TiCl}_{3}$ was picked for additive to heighten of hydrogenation and dehydrogenation rates of $\mathrm{Mg}$. $\mathrm{Mg}$ was used as a starting material because it is less expensive than $\mathrm{MgH}_{2}$. The preparation of $\mathrm{MgH}_{2}$ is quite hard; it requires high hydrogen pressures and long periods. In our previous works $[13,14]$, the best percentage of additives, to improve hydrogenation and dehydrogenation features of $\mathrm{Mg}$, was about ten. A specimen consisting of $90 \mathrm{wt} . \% \mathrm{Mg}$ and $10 \mathrm{wt} . \% \mathrm{TiCl}_{3}$, which includes $10 \mathrm{wt} . \%$ additive, was prepared by transformation-accompanying milling. The conditions for optimum transformationaccompanying milling, which were studied in our previous works $[15,16]$, were used for the preparation of specimens. Its hydrogenation and dehydrogenation features such as hydrogenation and dehydrogenation rates and P-C-T (equilibrium hydrogen pressure-composition-temperature) curve, were then studied. Hydrogenation was done under a relatively low hydrogen pressure $\left(1.2 \mathrm{MPa} \mathrm{H}_{2}\right)$ and dehydrogenation under a relatively high hydrogen pressure ( $0.1 \mathrm{MPa} \mathrm{H}_{2}$ ), compared with the hydrogen pressures applied in other works for the hydrogenation and dehydrogenation features of metal hydrides. We designated the specimen consisting of $90 \mathrm{wt} . \% \mathrm{Mg}$ and $10 \mathrm{wt} . \% \mathrm{TiCl}_{3}$ as $90 \mathrm{Mg}+10 \mathrm{TiCl}_{3}$. The hydrogenation and dehydrogenation properties of $90 \mathrm{Mg}+10 \mathrm{TiCl}_{3}$ were compared with those of oxide-added specimens, such as $90 \mathrm{Mg}+10 \mathrm{Fe}_{2} \mathrm{O}_{3}$ and $90 \mathrm{Mg}+10 \mathrm{MnO}$, and $90 \mathrm{Mg}+10 \mathrm{TaF}_{5}$ which were reported before.

\section{EXPERIMENTAL DETAILS}

Pure Mg powder (particle size $74-149 \mu \mathrm{m}$, purity 99.6\%, Alfa Aesar), and $\mathrm{TiCl}_{3}$ (Titanium (III) chloride, Aldrich) were utilized as the initiating substances.

Specimens were got ready in an argon atmosphere. Transformation-accompanying milling was performed at $250 \mathrm{rpm}$ in a ball mill (Planetary Mono Mill; Pulverisette 6 , Fritsch) in about $1.2 \mathrm{MPa} \mathrm{H}_{2}$. A $90 \mathrm{wt} . \% \mathrm{Mg}$ and $10 \mathrm{wt} . \%$ $\mathrm{TiCl}_{3}$ mixture with a weight of $8 \mathrm{~g}$ was mixed with 105 hardened steel balls of a total weight of $360 \mathrm{~g}$ in a sealed $250 \mathrm{ml}$ container made of stainless steel. The milling time was $6 \mathrm{~h}$ by iterating milling for $15 \mathrm{~min}$ and resting for $5 \mathrm{~min}$. Hydrogen was replenished every $2 \mathrm{~h}$.

The amount of hydrogen absorbed or desorbed was quantified as the hydrogenation or dehydrogenation reaction proceeds, using a Sievert-type volumetric hydrogenation and dehydrogenation apparatus [17]. During quantifying the amount of hydrogen absorbed or desorbed, the hydrogen pressure was maintained nearly constant by making up the absorbed hydrogen from a small reservoir of a measured volume during hydrogenation or taking out the desorbed hydrogen to the small reservoir during dehydrogenation. The weight of the specimen utilized for these measurements was $0.5 \mathrm{~g}$. After the absorbed and then desorbed hydrogen quantities were measured at $593 \mathrm{~K}$ under 1.2 and $0.1 \mathrm{MPa} \mathrm{H}_{2}$ for $1 \mathrm{~h}$, respectively, the specimen was then dehydrogenated at $623 \mathrm{~K}$ in vacuum for $2 \mathrm{~h}$. The $\mathrm{P}$ (equilibrium hydrogen pressure)-C (composition)-T (temperature) curve was obtained by repeating waiting for equilibrium and then measuring equilibrium hydrogen pressure and taking some hydrogen out of the reactor and then measuring the taken hydrogen quantity.

The phases in the specimens after transformationaccompanying milling and after hydrogenationdehydrogenation cycling were analyzed by X-ray diffraction (XRD) with $\mathrm{Cu} \mathrm{K} \alpha$ radiation in a powder diffractometer (Rigaku D/MAX 2500). Scanning electron microscope (SEM) micrographs of the specimens were obtained in a JSM-5900 SEM operated at $15 \mathrm{kV}$.

\section{RESULTS AND DISCUSSION}

The XRD diagram of $95 \mathrm{Mg}+10 \mathrm{TiCl}_{3}$ after transformation-accompanying milling showed that the specimen included $\mathrm{Mg}, \beta-\mathrm{MgH}_{2}$, and small quantities of $\gamma$ $\mathrm{MgH}_{2}$ and $\mathrm{TiH}_{1.924}$ phases. $\beta-\mathrm{MgH}_{2}$ and $\gamma-\mathrm{MgH}_{2}$ were built by the combination of $\mathrm{Mg}$ with hydrogen during transformation-accompanying milling. $\beta-\mathrm{MgH}_{2}$ and $\gamma-$ $\mathrm{MgH}_{2}$ are low-pressure and high-pressure forms of $\mathrm{MgH}_{2}$, respectively, each being belong to tetragonal and orthorhombic crystal systems. The combination of $\mathrm{Ti}$ with hydrogen during transformation-accompanying milling also led to the development of $\mathrm{TiH}_{1.924}$.

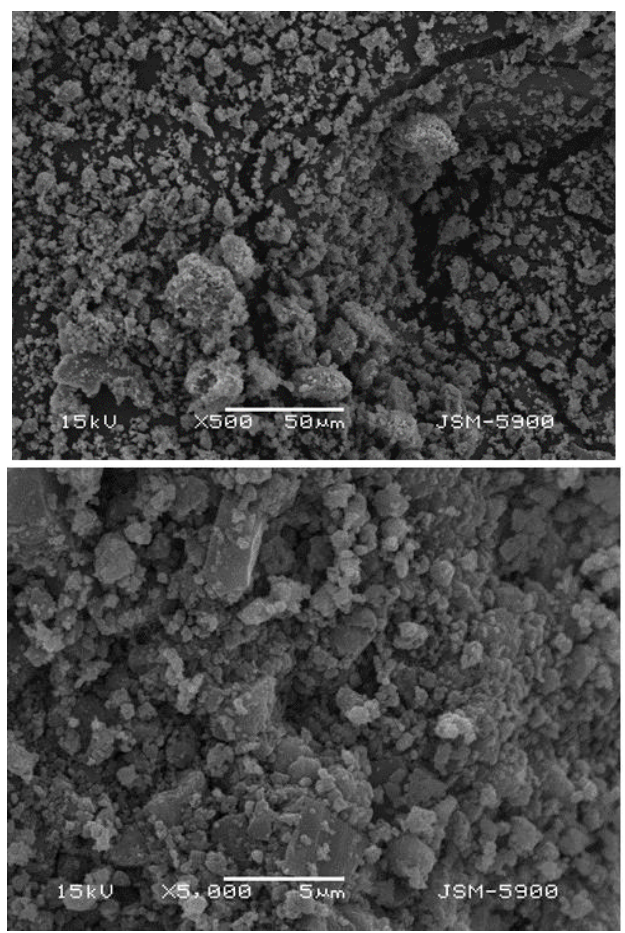

Fig. 1. SEM micrographs of $90 \mathrm{Mg}+10 \mathrm{TiCl}_{3}$ after transformation-accompanying milling

SEM micrographs of $90 \mathrm{Mg}+10 \mathrm{TiCl}_{3}$ after transformation-accompanying milling are exhibited in Fig. 1. The particle sizes are not homogeneous and the shapes of particles are irregular. Small particles are also observed on the surfaces of the relatively large particles. Some big particles have smooth surfaces. Agglomerates are also found.

The percentage of hydrogenated hydrogen, $\mathrm{H}_{\mathrm{a}}$, is defined as $100 \mathrm{x}$ (the weight of hydrogenated hydrogen / the sample weight). The change in the $\mathrm{H}_{\mathrm{a}}$ vs. $\mathrm{t}$ curve at $593 \mathrm{~K}$ in $1.2 \mathrm{MPa} \mathrm{H}_{2}$ according to the number of hydrogenation-dehydrogenation cycles, $C_{n}$, for $90 \mathrm{Mg}+10 \mathrm{TiCl}_{3}$ is shown in Fig. 2. At the first cycle, the hydrogenation rate is very high from the starting to $5 \mathrm{~min}$ 
around, and then severely low after $10 \mathrm{~min}$. It is believed that the very high hydrogenation rate until $5 \mathrm{~min}$ is due to hydrogen absorption by small particles, small particles on the surfaces of large particles, and outer sides, which have many hydrogen paths such as cracks, of large particles and agglomerates. The very low hydrogenation rate after $10 \mathrm{~min}$ is probably resulted from the absorption of hydrogen by the insides of particles, which can be hydrogenated after diffusion of hydrogen through growing hydride layers. As the number of hydrogenationdehydrogenation cycles increases from $C_{n}=1$ to $C_{n}=3$, the early hydrogenation rate increases and the amount of hydrogen absorbed in $60 \mathrm{~min}$ decreases. At $\mathrm{C}_{\mathrm{n}}=1$, the sample absorbs $4.06 \mathrm{wt}$ \% of hydrogen in $5 \mathrm{~min}, 5.09 \mathrm{wt} \%$ of hydrogen in $10 \mathrm{~min}, 5.57 \mathrm{wt} . \%$ of hydrogen in $30 \mathrm{~min}$, and $5.59 \mathrm{wt} . \%$ of hydrogen in $60 \mathrm{~min}$. The useful hydrogenation-dehydrogenation capacity is defined as the quantity of hydrogen absorbed in $60 \mathrm{~min}$. $90 \mathrm{Mg}+10 \mathrm{TiCl}_{3}$ has a useful hydrogenationdehydrogenation capacity of about $5.6 \mathrm{wt} \%$ at $\mathrm{C}_{\mathrm{n}}=1$. Table 1 presents the change in the absorbed hydrogen quantity with time for $90 \mathrm{Mg}+10 \mathrm{TiCl}_{3}$ at $593 \mathrm{~K}$ in 1.2 $\mathrm{MPa} \mathrm{H}_{2}$ at $\mathrm{C}_{\mathrm{n}}=1-3$.

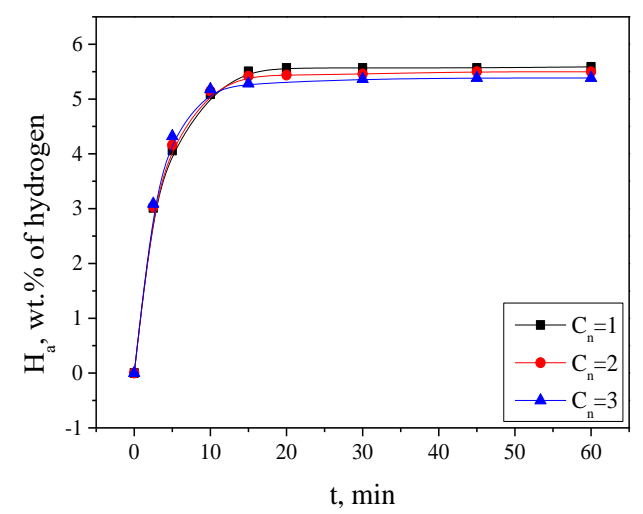

Fig. 2. Change in the $\mathrm{H}_{\mathrm{a}}$ vs. $\mathrm{t}$ curve at $593 \mathrm{~K}$ in $1.2 \mathrm{MPa} \mathrm{H}_{2}$ according to the number of hydrogenationdehydrogenation cycles, $\mathrm{C}_{\mathrm{n}}$, for $90 \mathrm{Mg}+10 \mathrm{TiCl}_{3}$

Table 1. Change in the absorbed hydrogen quantity with time for $90 \mathrm{Mg}+10 \mathrm{TiCl}_{3}$ at $593 \mathrm{~K}$ in $1.2 \mathrm{MPa} \mathrm{H}_{2}$ at $\mathrm{C}_{\mathrm{n}}=1-3$

\begin{tabular}{|l|c|c|c|c|c|}
\hline \multirow{2}{*}{$C_{n}=1$} & \multicolumn{5}{|c|}{ Absorbed hydrogen quantity (wt.\% of hydrogen) } \\
\cline { 2 - 6 } & $2.5 \mathrm{~min}$ & $5 \mathrm{~min}$ & $10 \mathrm{~min}$ & $30 \mathrm{~min}$ & $60 \mathrm{~min}$ \\
\hline & 3.01 & 4.06 & 5.09 & 5.57 & 5.59 \\
\hline$C_{n}=2$ & 3.03 & 4.16 & 5.15 & 5.46 & 5.50 \\
\hline$C_{n}=3$ & 3.09 & 4.32 & 5.18 & 5.37 & 5.38 \\
\hline
\end{tabular}

Fig. 3 shows the changes in the early hydrogenation rate and the quantity of hydrogen absorbed in $60 \mathrm{~min}, \mathrm{H}_{\mathrm{a}}$ (60 min), with the number of hydrogenationdehydrogenation cycles, $\mathrm{C}_{\mathrm{n}}$, at $593 \mathrm{~K}$ in $1.2 \mathrm{MPa}_{2}$ for $90 \mathrm{Mg}+10 \mathrm{TiCl}_{3}$. As $\mathrm{C}_{\mathrm{n}}$ increases, the early hydrogenation rate increases, whereas $\mathrm{H}_{\mathrm{a}}(60 \mathrm{~min})$ decreases. The increase in the early hydrogenation rate with hydrogenation-dehydrogenation cycling is believed due to decrease in size of the particles on the surface. The decrease in $\mathrm{H}_{\mathrm{a}} \quad(60 \mathrm{~min})$ with hydrogenationdehydrogenation cycling is thought owing to sintering of the particles inside the particles and agglomerates.

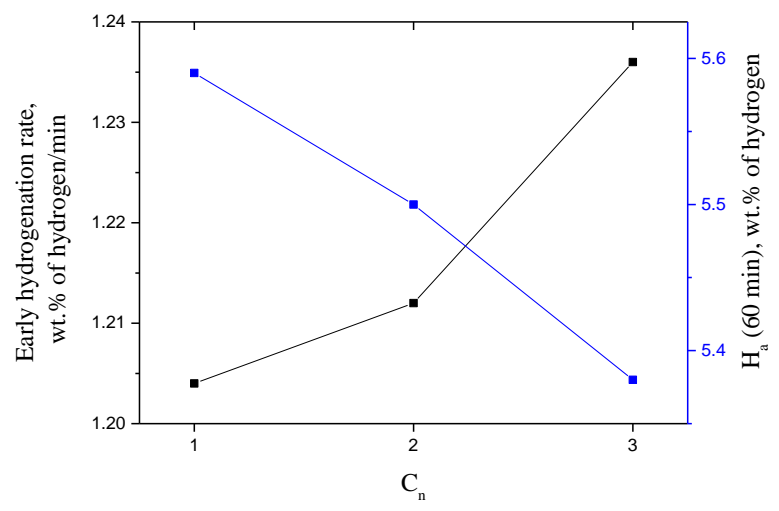

Fig. 3. Changes in the early hydrogenation rate and the quantity of hydrogen absorbed in $60 \mathrm{~min}, \mathrm{H}_{\mathrm{a}}(60 \mathrm{~min})$, with the number of hydrogenation-dehydrogenation cycles, $\mathrm{C}_{\mathrm{n}}$, at $593 \mathrm{~K}$ in $1.2 \mathrm{MPa} \mathrm{H}_{2}$ for $90 \mathrm{Mg}+10 \mathrm{TiCl}_{3}$

The percentage of desorbed hydrogen, $\mathrm{H}_{\mathrm{d}}$, is defined as $100 \mathrm{x}$ (the weight of desorbed hydrogen / the sample weight). The change in the $H_{d}$ vs. $t$ curve at $593 \mathrm{~K}$ in $0.1 \mathrm{MPa} \mathrm{H}_{2}$ according to the number of hydrogenationdehydrogenation cycles, $\mathrm{C}_{\mathrm{n}}$, for $90 \mathrm{Mg}+10 \mathrm{TiCl}_{3}$ is shown in Fig. 4.

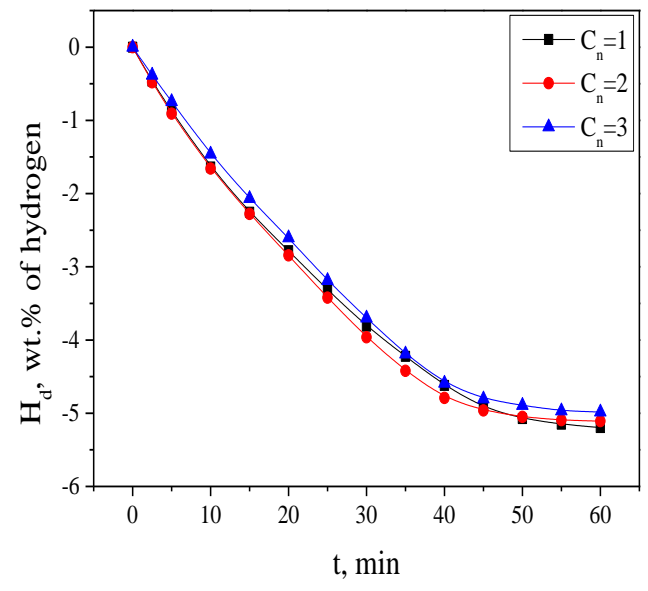

Fig. 4. Change in the $\mathrm{H}_{\mathrm{d}}$ vs. $\mathrm{t}$ curve at $593 \mathrm{~K}$ in $0.1 \mathrm{MPa} \mathrm{H}_{2}$ according to the number of hydrogenationdehydrogenation cycles, $\mathrm{C}_{\mathrm{n}}$, for $90 \mathrm{Mg}+10 \mathrm{TiCl}_{3}$

Table 2. Change in the desorbed hydrogen quantity with time for $90 \mathrm{Mg}+10 \mathrm{TiCl}_{3}$ at $593 \mathrm{~K}$ in $0.1 \mathrm{MPa} \mathrm{H}_{2}$ at $\mathrm{C}_{\mathrm{n}}=1-3$

\begin{tabular}{|c|c|c|c|c|c|}
\hline \multirow{4}{*}{$C_{n}=1$} & \multicolumn{5}{|c|}{ Desorbed hydrogen quantity (wt.\% of hydrogen) } \\
\cline { 2 - 6 } & $2.5 \mathrm{~min}$ & $5 \mathrm{~min}$ & $10 \mathrm{~min}$ & $30 \mathrm{~min}$ & $60 \mathrm{~min}$ \\
\cline { 2 - 6 } & 0.47 & 0.88 & 1.64 & 3.81 & 5.20 \\
\hline$C_{n}=2$ & 0.48 & 0.91 & 1.66 & 3.96 & 5.11 \\
\hline$C_{n}=3$ & 0.38 & 0.74 & 1.46 & 3.70 & 4.98 \\
\hline
\end{tabular}

The specimen has a slightly higher early dehydrogenation rates at $C_{n}=2$ than at $C_{n}=1$, and the early dehydrogenation rate at $C_{n}=3$ is lower than at $C_{n}=2$ and $\mathrm{C}_{\mathrm{n}}=1$. At $\mathrm{C}_{\mathrm{n}}=1$, the specimen desorbs $0.47 \mathrm{wt} \%$ of hydrogen in $2.5 \mathrm{~min}, 3.81 \mathrm{wt} \%$ of hydrogen in $30 \mathrm{~min}$, and $5.20 \mathrm{wt} . \%$ of hydrogen in $60 \mathrm{~min}$. At $\mathrm{C}_{\mathrm{n}}=1$, the quantity of hydrogen desorbed in $60 \mathrm{~min}$ is $93 \%$ of that absorbed in $60 \mathrm{~min}$. The quantity of hydrogen desorbed in 60 min decreases as the number of hydrogenationdehydrogenation cycles increases from 1 to 3 . Table 2 
presents the change in the desorbed hydrogen quantity with time for $90 \mathrm{Mg}+10 \mathrm{TiCl}_{3}$ at $593 \mathrm{~K}$ in $0.1 \mathrm{MPa} \mathrm{H}_{2}$ at $\mathrm{C}_{\mathrm{n}}=1-3$.

Fig. 5 shows the changes in the early dehydrogenation rate and the quantity of hydrogen desorbed in $60 \mathrm{~min}, \mathrm{H}_{\mathrm{d}}$ (60 min), with the number of hydrogenationdehydrogenation cycles, $\mathrm{C}_{\mathrm{n}}$, at $593 \mathrm{~K}$ in $1.2 \mathrm{MPa} \mathrm{H}_{2}$ for $90 \mathrm{Mg}+10 \mathrm{TiCl}_{3}$. As $\mathrm{C}_{\mathrm{n}}$ increases, the early dehydrogenation rate increases at $C_{n}=2$ and decreases at $C_{n}=3$. The early dehydrogenation rate at $C_{n}=3$ is lower than at $C_{n}=2$ and $C_{n}=1 . H_{d}(60 \mathrm{~min})$ decreases as $C_{n}$ increases from 1 to 3 .

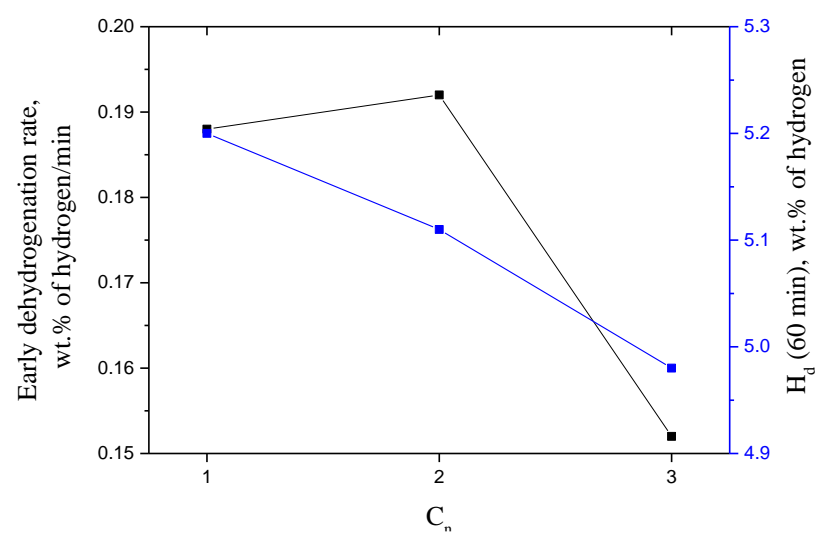

Fig. 5. Changes in the early dehydrogenation rate and the quantity of hydrogen desorbed in $60 \mathrm{~min}, \mathrm{H}_{\mathrm{d}}(60 \mathrm{~min})$, with the number of hydrogenation-dehydrogenation cycles, $\mathrm{C}_{\mathrm{n}}$, at $593 \mathrm{~K}$ in $1.2 \mathrm{MPa} \mathrm{H}_{2}$ for $90 \mathrm{Mg}+10 \mathrm{TiCl}_{3}$

Activation is a process which makes the sample have maximum reaction rates. For metal hydrides, it is performed by hydrogenation-dehydrogenation cycling. Fig. 2 - Fig. 5 show that the activation of $90 \mathrm{Mg}+10 \mathrm{TiCl}_{3}$ is not demanded.

The XRD diagram of $90 \mathrm{Mg}+10 \mathrm{TiCl}_{3}$ dehydrogenated at the $4^{\text {th }}$ hydrogenation-dehydrogenation cycle showed that the sample included $\mathrm{Mg}, \beta-\mathrm{MgH}_{2}, \mathrm{MgO}$, and a small amount of $\mathrm{TiH}_{1.924}$ phases. $\mathrm{TiH}_{1.924}$, which was formed after transformation-accompanying milling, was not dehydrogenated even after dehydrogenation at $623 \mathrm{~K}$ in vacuum for $2 \mathrm{~h}$. Titanium hydride $\left(\mathrm{TiH}_{2}\right)$ was also reported to form in the dehydrogenated $\mathrm{MgH}_{2}+4 \mathrm{~mol} \%$ $\mathrm{TiCl}_{3}$ of $\mathrm{Ma}$ et al.'s work [10]. This XRD diagram exhibited slightly narrower peaks and lower background than the XRD diagram of $90 \mathrm{Mg}+10 \mathrm{TiCl}_{3}$ after transformation-accompanying milling. This suggests that this specimen has better crystallinity than the specimen after transformation-accompanying milling.

The SEM micrographs of $90 \mathrm{Mg}+10 \mathrm{TiCl}_{3}$ dehydrogenated at the $4^{\text {th }}$ hydrogenation-dehydrogenation cycle are shown in Fig. 6. This specimen has particles of various sizes with a large number of small particles on their surfaces. Smooth surfaces of some big particles disappeared and small particles are found on the large particles. Particles are agglomerated. The particles on the surfaces are finer but the size of agglomerates is larger as compared with those after transformation-accompanying milling.

Fig. 7 shows a dehydrogenation P-C-T (equilibrium hydrogen pressure-composition-temperature) curve of $90 \mathrm{Mg}+10 \mathrm{TiCl}_{3}$ at $593 \mathrm{~K}$.
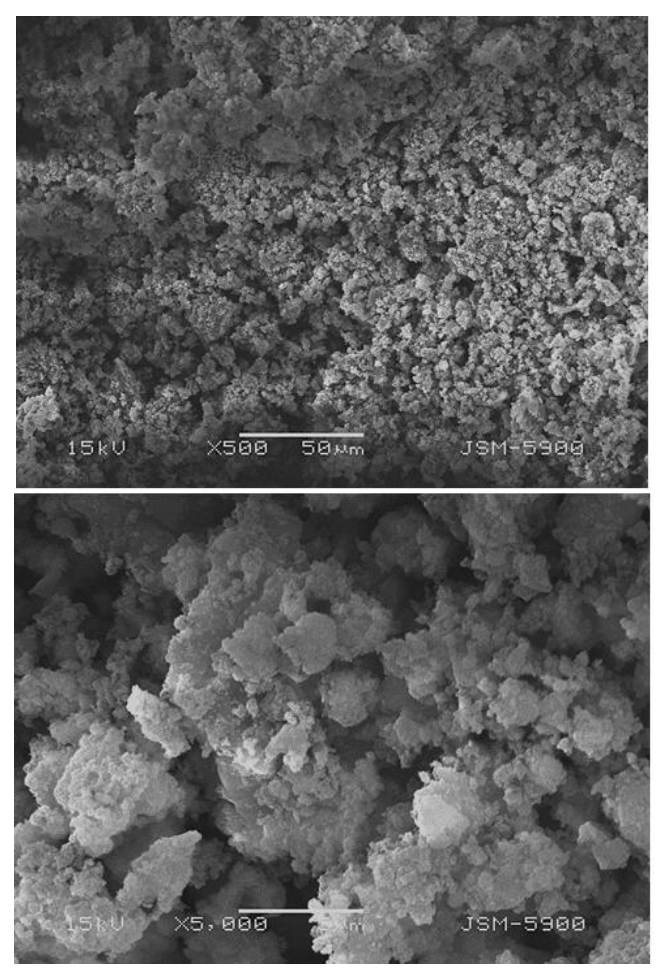

Fig. 6. SEM micrographs of $90 \mathrm{Mg}+10 \mathrm{TiCl}_{3}$ dehydrogenated at the $4^{\text {th }}$ hydrogenation-dehydrogenation cycle

The hydrogen pressure decreases abruptly from a hydrogen pressure of about $1.17 \mathrm{MPa}$ to about $0.27 \mathrm{MPa}$, then maintains almost constant at about $0.25 \mathrm{MPa}$, and finally decreases slowly. The equilibrium plateau pressure (about $0.25 \mathrm{MPa}$ ) is found at an $\mathrm{H}_{\mathrm{d}}$ range of 5.0-1.0 wt.\% of hydrogen. The slope of the equilibrium plateau pressure is believed to appear because other phases, such as titanium hydride $\left(\mathrm{TiH}_{1.924}\right)$, are present in addition to $\mathrm{Mg}-\mathrm{H}$ solid solution and magnesium hydride. The $90 \mathrm{Mg}+10 \mathrm{TiCl}_{3}$ specimen contains a very small amount of titanium hydride and the main hydride phase of the $90 \mathrm{Mg}+10 \mathrm{TiCl}_{3}$ specimen is $\mathrm{MgH}_{2}$. The equilibrium plateau pressure of about $0.25 \mathrm{MPa}$ for $90 \mathrm{Mg}+10 \mathrm{TiCl}_{3}$ at $593 \mathrm{~K}$ is very similar to that of the $\mathrm{Mg}-\mathrm{H}$ system at $593 \mathrm{~K}$ reported by Stampfer et al. [18]. The data of Stampfer et al. [18] showed that the equilibrium plateau pressure in the $\mathrm{Mg}-\mathrm{H}$ system at $593 \mathrm{~K}$ is $0.27 \mathrm{MPa}$. The hydrogen-storage capacity of the sample is about $5.0 \mathrm{wt} . \%$. This sample has an effective hydrogen-storage capacity (the quantity of hydrogen absorbed for $60 \mathrm{~min}$ ) of about $5.6 \mathrm{wt} . \%$. The hydrogen-storage capacity of the sample is believed to be smaller than the effective hydrogen-storage capacity because the sample was stored for a couple of months in a glove box and slightly contaminated.

In our former research [19], the hydrogenation and dehydrogenation features were investigated for $90 \mathrm{Mg}+10 \mathrm{Fe}_{2} \mathrm{O}_{3}, 90 \mathrm{Mg}+10 \mathrm{Fe}_{2} \mathrm{O}_{3}$ got ready by spray conversion, $90 \mathrm{Mg}+10 \mathrm{MnO}$, and $90 \mathrm{Mg}+10 \mathrm{SiO}_{2}$ specimens, which were made by transformationaccompanying milling for $2 \mathrm{~h}$ under the milling conditions like those to make $90 \mathrm{Mg}+10 \mathrm{TiCl}_{3}$ specimen. $90 \mathrm{Mg}+10 \mathrm{Fe}_{2} \mathrm{O}_{3}$ and $90 \mathrm{Mg}+10 \mathrm{MnO}$ had relatively high hydrogenation or dehydrogenation speeds. In another previous work of our group [20], the hydrogenation and dehydrogenation features were investigated for 
$90 \mathrm{Mg}+10 \mathrm{TaF}_{5}$, which were made by transformationaccompanying milling under the milling conditions like those to make $90 \mathrm{Mg}+10 \mathrm{TiCl}_{3}$ specimen. $90 \mathrm{Mg}+10 \mathrm{TaF}_{5}$ showed quite high hydrogenation and dehydrogenation speeds.

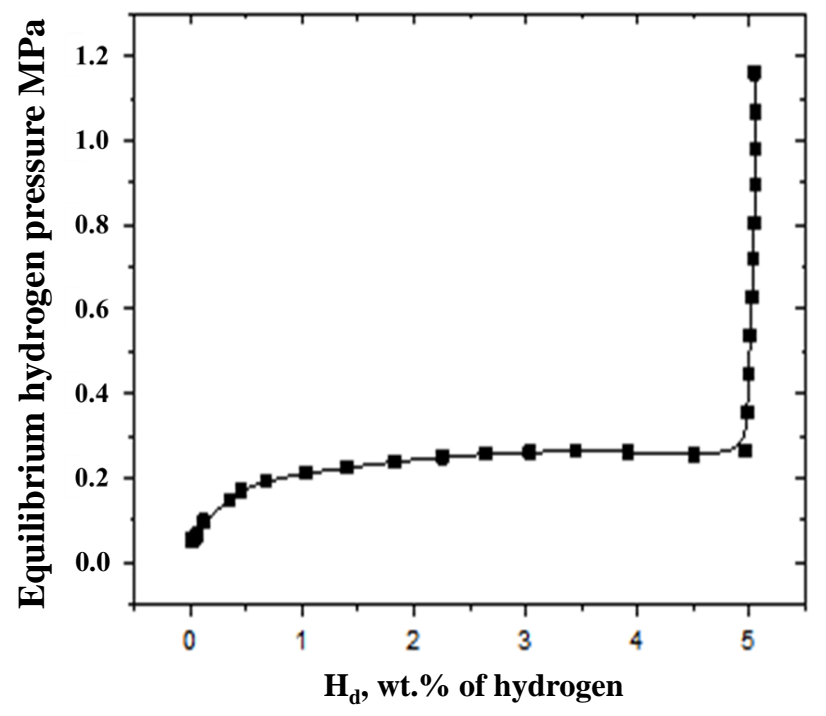

Fig. 7. Dehydrogenation P-C-T (equilibrium hydrogen pressurecomposition-temperature) curve of $90 \mathrm{Mg}+10 \mathrm{TiCl}_{3}$ at $593 \mathrm{~K}$

The $\mathrm{H}_{\mathrm{a}}$ vs. $\mathrm{t}$ curves at $593 \mathrm{~K}$ in $1.2 \mathrm{MPa}_{2}$ at $\mathrm{C}_{\mathrm{n}}=1$ for $90 \mathrm{Mg}+10 \mathrm{TiCl}_{3}, \mathrm{Mg}$ [21], $90 \mathrm{Mg}+10 \mathrm{Fe}_{2} \mathrm{O}_{3}$ [19], $90 \mathrm{Mg}+10 \mathrm{MnO}$ [19], and $90 \mathrm{Mg}+10 \mathrm{TaF}_{5}$ [20] were compared. $\mathrm{Mg}, 90 \mathrm{Mg}+10 \mathrm{Fe}_{2} \mathrm{O}_{3}, 90 \mathrm{Mg}+10 \mathrm{MnO}$, and $90 \mathrm{Mg}+10 \mathrm{TaF}_{5}$ were made under the milling conditions like those to make $90 \mathrm{Mg}+10 \mathrm{TiCl}_{3}$ specimen. $\mathrm{Mg}$ absorbed hydrogen extremely slowly. $90 \mathrm{Mg}+10 \mathrm{TiCl}_{3}$ had a higher early hydrogenation rate and a larger quantity of hydrogen absorbed in $60 \mathrm{~min}$ than $\mathrm{Mg}$, $90 \mathrm{Mg}+10 \mathrm{Fe}_{2} \mathrm{O}_{3}, \quad 90 \mathrm{Mg}+10 \mathrm{MnO}, \quad$ and $90 \mathrm{Mg}+10 \mathrm{TaF}_{5} .90 \mathrm{Mg}+10 \mathrm{TiCl}_{3}$ had the highest early hydrogenation rate, followed in a decreasing order by $90 \mathrm{Mg}+10 \mathrm{TaF}_{5}, \quad 90 \mathrm{Mg}+10 \mathrm{Fe}_{2} \mathrm{O}_{3}, \quad 90 \mathrm{Mg}+10 \mathrm{MnO}$, and $\mathrm{Mg}$. $90 \mathrm{Mg}+10 \mathrm{TiCl}_{3}$ had the largest quantity of hydrogen absorbed in $60 \mathrm{~min}$, followed in a decreasing order by $90 \mathrm{Mg}+10 \mathrm{Fe}_{2} \mathrm{O}_{3}, \quad 90 \mathrm{Mg}+10 \mathrm{TaF}_{5}$, $90 \mathrm{Mg}+10 \mathrm{MnO}$, and $\mathrm{Mg}$. $90 \mathrm{Mg}+10 \mathrm{TiCl}_{3}$ absorbed $4.06 \mathrm{wt} . \%$ of hydrogen in $5 \mathrm{~min}, 5.09 \mathrm{wt} . \%$ of hydrogen in $10 \mathrm{~min}, 5.57 \mathrm{wt} . \%$ of hydrogen in $30 \mathrm{~min}$, and $5.59 \mathrm{wt} . \%$ of hydrogen in $60 \mathrm{~min}$. $90 \mathrm{Mg}+10 \mathrm{Fe}_{2} \mathrm{O}_{3}$ absorbed $2.41 \mathrm{wt} . \%$ of hydrogen in $2.5 \mathrm{~min}, 3.52 \mathrm{wt} . \%$ of hydrogen in $5 \mathrm{~min}, 4.26 \mathrm{wt} . \%$ of hydrogen in $10 \mathrm{~min}, 4.84 \mathrm{wt} . \%$ of hydrogen in $30 \mathrm{~min}$, and $5.16 \mathrm{wt} \%$ of hydrogen in $60 \mathrm{~min}$. $\mathrm{Mg}$ absorbed $0.08 \mathrm{wt} \%$ of hydrogen in $2.5 \mathrm{~min}$, and 0.14 wt. $\%$ of hydrogen in $60 \mathrm{~min}$.

The transformation-accompanying milling of $\mathrm{Mg}$ with $\mathrm{TiCl}_{3}$, which forms $\beta-\mathrm{MgH}_{2}, \gamma-\mathrm{MgH}_{2}$, and $\mathrm{TiH}_{1.924}$ is thought to produce defects on the surface and inside $\mathrm{Mg}$ particle, to make new clean surfaces, and to curtail the $\mathrm{Mg}$ particle sizes. Producing of defects makes easy nucleation of magnesium hydride, making of new clean surfaces increases the reactivity of particles with hydrogen, and reduction in the $\mathrm{Mg}$ particle sizes shortens diffusion distances of hydrogen atoms. These effects increase the hydrogenation and dehydrogenation rates of $\mathrm{Mg}$. The formed $\beta-\mathrm{MgH}_{2}, \gamma-\mathrm{MgH}_{2}$, and $\mathrm{TiH}_{1.924}$ are considered to make these effects stronger.

The higher early hydrogenation rates of $90 \mathrm{Mg}+10 \mathrm{TiCl}_{3}$ and $90 \mathrm{Mg}+10 \mathrm{TaF}_{5}$ than those of $90 \mathrm{Mg}+10 \mathrm{Fe}_{2} \mathrm{O}_{3}$ and $90 \mathrm{Mg}+10 \mathrm{MnO}$ indicate that the effects of the addition of halides on the increase in the hydrogenation rates of $\mathrm{Mg}$ are stronger than those of the addition of oxides.

\section{CONCLUSIONS}

The activation of $90 \mathrm{Mg}+10 \mathrm{TiCl}_{3}$ was not demanded. $90 \mathrm{Mg}+10 \mathrm{TiCl}_{3}$ had a useful hydrogenationdehydrogenation capacity of about $5.6 \mathrm{wt} . \%$. At $\mathrm{C}_{\mathrm{n}}=1$, the specimen absorbed $4.06 \mathrm{wt} \%$ of hydrogen in $5 \mathrm{~min}$, $5.09 \mathrm{wt} . \%$ of hydrogen in $10 \mathrm{~min}, 5.57 \mathrm{wt} . \%$ of hydrogen in $30 \mathrm{~min}$, and $5.59 \mathrm{wt} . \%$ of hydrogen in $60 \mathrm{~min}$ at $593 \mathrm{~K}$ in $1.2 \mathrm{MPa} \mathrm{H}_{2}$. At $\mathrm{C}_{\mathrm{n}}=1$, the specimen desorbed $0.47 \mathrm{wt} . \%$ of hydrogen in $2.5 \mathrm{~min}, 3.81 \mathrm{wt} . \%$ of hydrogen in $30 \mathrm{~min}$, and $5.20 \mathrm{wt} . \%$ of hydrogen in $60 \mathrm{~min}$ at $593 \mathrm{~K}$ in $0.1 \mathrm{MPa} \mathrm{H} \cdot \gamma-\mathrm{MgH}_{2}$ was formed in $90 \mathrm{Mg}+10 \mathrm{TiCl}_{3}$ after transformation-accompanying milling. $\mathrm{TiH}_{1.924}$, which was formed after transformation-accompanying milling, was not dehydrogenated even after dehydrogenation at $623 \mathrm{~K}$ in vacuum for $2 \mathrm{~h}$. As the number of hydrogenationdehydrogenation cycles increased from $C_{n}=1$ to $C_{n}=3$, the early hydrogenation rate increased due to decrease in size of the particles on the surface and the quantity of hydrogen absorbed in 60 min decreased due to sintering of the particles inside the particles and agglomerates. The P$\mathrm{C}-\mathrm{T}$ curve at $593 \mathrm{~K}$ showed an equilibrium plateau pressure at about $0.25 \mathrm{MPa} .90 \mathrm{Mg}+10 \mathrm{TiCl}_{3}$ had a higher early hydrogenation rate and a larger quantity of hydrogen absorbed in $60 \mathrm{~min}$ than $90 \mathrm{Mg}+10 \mathrm{TaF}_{5}$, $90 \mathrm{Mg}+10 \mathrm{Fe}_{2} \mathrm{O}_{3}, \quad 90 \mathrm{Mg}+10 \mathrm{MnO}$, and $\mathrm{Mg}$, the hydrogenation and dehydrogenation features of which were before informed of.

\section{Acknowledgements}

This research was supported by Basic Science Research Program through the National Research Foundation (NRF) of Korea funded by the Ministry of Education, Science and Technology (Grant number 2011-0023566).

\section{REFERENCES}

1. Han, J.S., Kim, S.J., Kim, D.I. A Study of the PressureComposition-Temperature Curve of $\mathrm{Mg}\left(\mathrm{BH}_{4}\right)_{2}$ by Sievert's Type Apparatus Korean Journal of Metals and Materials 53 2015: pp. 815-820.

2. Rusman, N.A.A., Dahari, M. A Review on the Current Progress of Metal Hydrides Material for Solid-State Hydrogen Storage Applications International Journal of Hydrogen Energy 41 2016: pp. 12108-12126. https://doi.org/10.1016/j.ijhydene.2016.05.244

3. Ogawa, S., Fujimoto, T., Mizutani, T., Ogawa, M., Uchiyama, N., Kato, K., Ohta, T., Yoshida, T., Yagi, S. Hydrogen Storage of Binary Nanoparticles Composed of $\mathrm{Mg}$ and $\mathrm{Pd}$ International Journal of Hydrogen Energy 40 2015: pp. 11895-11901.

4. Fujimoto, T., Ogawa, S., Kanai, T., Uchiyama, N., Yoshida, T., Yagi. S. Hydrogen Storage Property of 
Materials Composed of $\mathrm{Mg}$ Nanoparticles and $\mathrm{Ni}$ Nanoparticles Fabricated by Gas Evaporation Method International Journal of Hydrogen Energy 40 2015: pp. $11890-11894$.

https://doi.org/10.1016/j.ijhydene.2016.02.108

5. Yuan, Z., Yang, T., Bu, W., Shang, H., Qi, Y., Zhang, Y. Structure, Hydrogen Storage Kinetics and Thermodynamics of $\mathrm{Mg}$-Base $\mathrm{Sm}_{5} \mathrm{Mg}_{41}$ Alloy International Journal of Hydrogen Energy 41 2016: pp. 5994-6003.

6. Shao, H., Asano, K., Enoki, H., Akiba, E. Fabrication and Hydrogen Storage Property Study of Nanostructured Mg-Ni-B Ternary Alloys Journal of Alloys and Compounds 479 2009: pp. 409-413. https://doi.org/10.1016/j.jallcom.2008.12.067

7. Zhang, Y., Yuan, Z., Yang, T., Feng, D., Cai, Y., Zhao, D. An Investigation on Hydrogen Storage Thermodynamics and Kinetics of $\mathrm{Pr}-\mathrm{Mg}-\mathrm{Ni}$-Based $\mathrm{PrMg}_{12}$-Type Alloys Synthesized by Mechanical Milling Journal of Alloys and Compounds 688 2016: pp. 585-593.

8. El Khatabi, M., $\quad$ Bhihi, M., $\quad$ Naji, S., $\quad$ Labrim, H., Benyoussef, A., El Kenz, A., Loulidi, M. Study of Doping Effects with 3d and 4d-Transition Metals on the Hydrogen Storage Properties of $\mathrm{MgH}_{2}$ International Journal of Hydrogen Energy 41 2016: pp. 4712-4718. https://doi.org/10.1016/j.ijhydene.2016.01.001

9. Wu, D., Ouyang, L., Wu, C., Gu, Q., Wang, H., Liu, J., Zhu, M. Phase Transition and Hydrogen Storage Properties of $\mathrm{Mg}_{17} \mathrm{Ba}_{2}$ Compound Journal of Alloys and Compounds 690 2017: pp. 519-522.

10. Ma, L.P., Kang, X.D., Dai, H.B., Liang, Y., Fang, Z.Z., Wang, P.J., Wang, P., Cheng, H.M. Superior Catalytic Effect of $\mathrm{TiF}_{3}$ over $\mathrm{TiCl}_{3}$ in Improving the Hydrogen Sorption Kinetics of $\mathrm{MgH}_{2}$ : Catalytic Role of Fluorine anion Acta Materialia 57 2009: pp. 2250-2258. https://doi.org/10.1016/j.actamat.2009.01.025

11. Malka, I.E., Czujko, T., Bystrzycki, J. Catalytic Effect of Halide Additives Ball Milled with Magnesium Hydride International Journal of Hydrogen Energy 35 2010: pp. $1706-1712$.

12. Malka, I.E., Pisarek, M., Czujko, T., Bystrzycki, J. A Study of the $\mathrm{ZrF}_{4}, \mathrm{NbF}_{5}, \mathrm{TaF}_{5}$, and $\mathrm{TiCl}_{3}$ Influences on the $\mathrm{MgH}_{2}$ Sorption Properties International Journal of Hydrogen Energy 36 2011: pp. 12909-12917. https://doi.org/10.1016/j.ijhydene.2011.07.020
13. Song, M.Y., Ivanov, E., Darriet, B., Pezat, M., Hagenmuller, $\mathbf{P}$. Hydriding and Dehydriding Characteristics of Mechanically Alloyed Mixtures Mg-x wt.\% $\mathrm{Ni}(\mathrm{x}=5,10,25$, and 55) Journal of the LessCommon Metals 131 1987: pp. 71-79. https://doi.org/10.1016/0022-5088(87)90502-9

14. Song, M.Y., Kwak, Y.J., Lee, S.H., Park, H.R. Increase in the Hydrogen Release Rate of $\mathrm{MgH}_{2}$ by Grinding in a Hydrogen Atmosphere with $\mathrm{Ni}$ Added Journal of Nanoscience and Nanotechnology 16 2016: pp. 10508 - 10514.

15. Song, M.Y., Kwon, I.H., Kwon, S.N. Park, C.G., Park, H.R., Bae, J.S. Preparation of Hydrogen-Storage Alloy $\mathrm{Mg}-10 \mathrm{wt} \% \quad \mathrm{Fe}_{2} \mathrm{O}_{3}$ under Various Milling Conditions International Journal of Hydrogen Energy 31 2006: pp.43-47. https://doi.org/10.1016/j.ijhydene.2005.03.008

16. Song, M.Y., Kwak, Y.J., Lee, S.H., Park, H.R. Enhancement of Hydrogen Storage Characteristics of $\mathrm{Mg}$ by Addition of Nickel and Niobium (V) Fluoride via Mechanical Alloying Korean Journal of Metals and Materials 54 2016: pp. 210-216.

17. Kwon, S.N. Improvement of the Hydrogen absorption and Desorption Kinetics of $\mathrm{Mg}$ by Catalytic Effects of $\mathrm{Fe}_{2} \mathrm{O}_{3}$ and $\mathrm{Ni}$ Thesis of Master of Engineering Chonbuk National University, Republic of Korea 2008: pp.20-22.

18. Stampfer, J.F.Jr., Holley, C.E.Jr., Suttle, J.F. The Magnesium-Hydrogen System Journal of American Chemical Society 82 1959: pp. 3504-3508. https://doi.org/10.1021/ja01499a006

19. Song, M.Y., Kwon, I.H., Kwon, S.N., Park, C.G., Hong, S.H., Bae, J.S., Mumm, D.R. Hydrogen-Storage Properties of Mg-Oxide Alloys Prepared by Reactive Mechanical Grinding Journal of Alloys and Compounds 415 2006: pp. 266-270.

20. Kwak, Y.J., Lee, S.H., Park, H.R., Song, M.Y. Hydriding and Dehydriding Reactions of $\mathrm{Mg}_{\mathrm{xTaF}} \mathrm{xT}_{5}(\mathrm{x}=0$, 5 and 10) Prepared via Reactive Mechanical Grinding Korean Journal of Metals and Materials 52 2014: pp. $957-962$.

21. Song, M.Y., Kwak, Y.J., Lee, S.H., Park, H.R. Hydrogen Storage Properties of Pure $\mathrm{Mg}$ Korean Journal of Metals and Materials 52 2014: pp. $293-297$. https://doi.org/10.3365/KJMM.2014.52.4.293 